\title{
The Thinking of Humanistic Education Based on the Modern Vocational Education System
}

\author{
Wenxue Liu \\ College of Mechanical Engineering \\ Hebei University of Science and Technology \\ Shijiazhuang, Hebei, China \\ Lwxshlcx@163.com
}

\author{
Shuyan Zhang \\ Department of Information Engineering and Automation \\ Hebei College of Industry and Technology \\ Shijiazhuang, Hebei, China \\ Zhshyan@126.com
}

\author{
Juanyin Liu \\ Department of Basic education \\ Hebei College of Industry and Technology \\ Shijiazhuang, Hebei, China \\ Liujuanyin666@163.com
}

\begin{abstract}
According to the current status and existing problems on humanistic education in Hebei province. This paper demonstrates the necessity of construction of humanistic cultivation system through special research, comprehensive analysis and empirical research methods. This paper also put forward some Modes of humanistic training system based on the modern occupation education.
\end{abstract}

Keywords-modern vocational education; humanity accomplish ment; training mode

\section{FOREWORD}

Humanity accomplishment is the power of the sustainable development of the occupation college graduates. the development of our country's occupation education has began to shift from the scale development to the modern occupation education system construction since 2011[1], the main work of The modern occupation education is to educate every students, is to emphasize the lifelong development. Strengthen the students' humanities can improve the quality of education and have great benefits for the country. It can enrich the connotation of modern occupation education system and also provide strong talent support for the construction of modern industrial system. Humanistic Education's mission is to develop the students' personality, comprehensive progress and provide the appropriate basis for lifelong learning. It's free and full development as the ultimate goal, and to achieve the harmonious development of humanistic education emphasizes the value of education[2][3]. Humanities content includes humanistic knowledge and humanistic spirit. However, the human spirit does not mean that human knowledge. Therefore, to develop humanities, just enhance human knowledge is not enough, more importantly, personally, strengthen cultural accomplishment. So how to strengthen the students' humanity accomplishment and train them as the talent of the social construction is also a subject which we should make a deep study[4].

\section{STRENGTHEN THE HUMANITIES ACCOMPLISHMENT IS THE INHERENT REQUIREMENT OF MODERN OCCUPATION EDUCATION SYSTEM CONSTRUCTION}

\section{A. Humanities Accomplishment Research is the Inevitable} Development of the Modern Occupation Education System

The national occupation education and adult education video conference in 2011 has pointed out that:" the development of the vocational education has stepped into a new stage that is the system construction. the modern vocational education system construction has become the central mission which can promote the vocational education reform and development over the next 10 years especially during the 12th Five-Year Plan period." The purpose of Modern vocational education system is to improve students' vocational core ability, however, the core competence of students' profession requires the training through the humanities accomplishment education.

\section{B. Carry out the Humanities Accomplishment Education is the Need Of Social Development}

The humanities accomplishment education can mould excellent humanistic spirit and realize the human being's integrated development. Carrying out the humanities accomplishment education is very important both on the strengthen connotation construction of modern vocational education and the promotion of talent training quality. With the development and prosperity of social and cultural life, the way of thinking has become more independent, selective, and changeable, Civilization and progress of the society needs high-quality people to highlight. as modernization builders the vocational education students needs to strengthen their humanities accomplishment and improve their vocational core ability, It is the requirement of social development. Further more, modern technology has brought many negative effects to our society, we needs some people with ethical conscience and humanistic spirit to check and control those kinds of negative 
effects. Obviously, remodeling Humanistic quality in modern vocational education is not only necessary in theory, but also urgent in reality.

\section{HUMANISTIC CULTIVATION STATUS QUO AND THE QUESTIONS EXISTED IN THE MODERN VOCATIONAL EDUCATION}

\section{A. Students' Humanistic Cultivation Status Quo in the Modern Vocational Education}

1) The lack of humanities knowledgeThe modern vocational education system construction has just started, it is still in the testing stage and has not established a system of mature mechanism. The old education concept "Skills rather than human" is still exists, some vocational colleges pay much attention on the students' employment rate and the cultivation of students' practical ability, neglecting the human development which caused the lack realization of students' humane knowledge and the lack of interests on study. the reflection mainly on the poor ability of language expression, the students can not understand project requirements and communicate with the team members effectively, they are not good at dealing with interpersonal relationships and can not integrate into the team work, especially when they write a project plan, there are many spelling mistakes and The words can not convey the meaning, it is difficult to reflect their professional literacy.

2) Humanities accomplishment is not highThe vocational college students' lack of humane knowledge which caused the lack of human spirit and the low of humanities accomplishment mainly reflected on their Fuzzy ideals and beliefs, spiritual emptiness, lack of sense of responsibility, lack of commitment[5]; they eager for quick success and instant benefit; And when the conflict happens, blaming each other, not to find reasons from itself; Psychological quality is poor and has weak ability of resisting frustration. The lack of humanistic education and spiritual leads to defects in personnel training, and a direct impact on the healthy development of society.

\section{B. Schools' Humanistic Cultivation Status Quo in the Modern Vocational Education}

Because modern vocational education system is imperfect, different levels in different parts of modern vocational education schools in humanities education there is a big difference. The prevalence of secondary vocational education school education for humanities degree of attention is not enough, humanities curriculum gradually being weakened[6]; Higher vocational education schools because too much attention to the students' employment rate, will focus on theoretical knowledge and professional skills training on professional practice, ignoring the humanities education, resulting in students not interested in human knowledge, that is a burden that causes improving the quality of employment. In vocational colleges in the humanities curriculum, there are also many problems, such as the course of duplication, lack of effective convergence; teaching in the form of rigid, lack of vividness, Some vocational schools still exist humanities education more centralized management, repetitive education more in-depth education can not, thus affecting the actual effect of humanities education.

\section{HUMANITIES ACCOMPLISHMENT TRAINING MODEL ON MODERN OCCUPATION EDUCATION SYSTEM}

\section{A. Update the Vocational Education Conception}

Conception can lead the education practice develop smoothly, but there are many vocational institutions can not abandon the utility of the occupation education, naturally or half unconsciously against the purpose of vocational education development, Ignore or weaken the educational function of vocational education, hinder the humanities accomplishment education. As we all know, vocational education can serve the development of the social economy directly, has a great influence on economic restructuring and upgradation, has closely relationship with society and economy, so the talent educated by vocational education should have a higher humanities literacy in order to be qualified for the industry after transformation and upgrading. Otherwise, our industry can not form economic scale and benefit, not to mention the implementation.

So vocational education must keep pace with the times, renew ideas, guided by scientific development concept. Establish a modern vocational education conception "comprehensive development, everybody can be a talent, Maximize everybody's talents", make a full excavation to use their own educational advantages, seize the opportunity of the transformation and upgrade of social economy, establish a clear educational objective, put The humanistic quality education throughout the course of talent training, focusing on students' humanities accomplishment education, overcoming the thought of instant benefit, Improving the comprehensive quality during personnel training, output "satisfied" graduates on their occupation post to the society.

\section{B. Build Spiritual Culture On Campus}

Ability depends on training, quality depends on reforming. So no matter a capacity cultivation or quality reformation needs create a good cultural atmosphere and humanities environment[7]. Campus Spiritual culture is regarded as "college spirit" it is the concentrated reflection of college nature, personality and mental outlook. Campus Spiritual culture includes the campus history and the common cultural ideas, identity values and life concepts agreed by all the staff and students, it is reflected on school spirit, teaching style, study style, class style and interpersonal relationship of this college. Spiritual culture is a deep culture, spiritual culture on campus can provide a special education atmosphere, it can be a invisible educational power that Influence students' moral, emotion and thought subliminally.

Therefore the campus spiritual culture must be the focus of the campus culture; we can through strengthen soft environment construction such as school spirit, teaching style, study style, work style and the academic atmosphere to build our school culture which can reflect Chinese characteristics, time features and vocational education regulation. Through strengthen the spreading of excellent Chinese cultural knowledge and the influence of education to improve the students' Humanistic quality. 


\section{Establish the Humanities Accomplishment Curriculum system}

Humanistic quality training objective can be achieved through the humanities curriculum system. humanistic quality education is a system project[8], the construction of humanities accomplishment curriculum system needs establish a whole concept of all the curriculum, obey the rules of professional talent development, it needs reasonable higher standard design, overall coordination, should avoid set this course because of somebody, should have clear objectives on teaching contents, should reflect scientifically on the teaching schedule, should focus on creation on teaching mode, should make a integration and effective cohesion between overt curriculum and hidden curriculum during the humanistic quality education, make a highly unify between professional courses and humanities accomplishment curriculum[9], so the students can internalize humanities knowledge as their own outlook on world, outlook on life and values, through mutual penetration and coordination between humanities courses and professional courses to form a strong curriculum system in order to promote the harmonious development of students' humanities accomplishment, professionalism and occupation accomplishment, to improve students' Humanistic qualities scientifically.

\section{Improve the Teachers' Humanistic Quality}

"The process of humanistic education is the process of experiencing common feeling, experience and soul sublimation both educators and the educated". Humanistic education is a long-term process of internalization, at college, the teacher is the model nearest to the students, so teacher' actions can have greater influence on students than words. Building a teaching team with high humanistic qualities is the key points on realizing humanistic quality education on the modern occupation education. First of all, the leadership should attach great importance to the matter. We should pay Overall consideration, formulate preferential policy, introduce outstanding talent to lead the humanistic education, strengthen the education for teachers who in charge of humanities courses, refer it as important as the professional teacher training status, promote their teaching ability. Second, we should improve all staff's Humanistic quality. The teachers' humanistic qualities influence students directly, deeply, lastingly. The humanities quality of teachers has a direct influence on the students' humanistic literacy level, only the teachers with higher humanities can guide the students' humanities progress. Third, Professional teachers can excavate the humanistic factors in teaching, be good at summing up the humanistic spirit.

\section{E. Construct Humanities Education'S Safeguard Mechanism}

Modern Vocational Education System, determines the modern vocational education humanities education must have a systematic, hierarchical, openness [7]. This requires that vocational education schools must depart from the school as a whole, changing the concept of vocational education. Under the guidance of the modern concept of vocational education, set scientific and rational management agencies to clear management responsibilities of various departments. Strengthen cooperation and close coordination. Establish and improve relevant rules and regulations through the protection of the execution of humanities education, so that penetrated into all aspects of humanities education, the formation of a culture of humanities education, so as to effectively promote vocational education student humanistic accomplishment.

\section{CONCLUSION}

With the transition and upgrade of social economy, the adjustment of industrial structure, the establishment of the modern occupation education system, vocational education plays a more and more important role in the talents training, so the Humanistic Quality Education becomes more important. Although it is a very difficult project, not accomplish at one stroke, but as long as we make carefully planning, pay close attention to implementation, we can close to the target and cultivate high- quality technical talents for the society[6] [10].

\section{REFERENCES}

[1] Ma Shuchao, Fan wei, Guo yang, Thoughts of several policy system on the construction of the modern occupation education. Decision reference, 2011.21:1-6

[2] Dr.NimrodAloni.Humanistic.Education.[DB/OL].http://www.ffst.hr/EN CYCLOPAEDIA/humanistic_education.htm.date:Nov.3,2007

[3] Bi Chunyi. Humanistic Education and College English Teaching. Read and Write Periodical. Vol. 5 No.1.January 2008

[4] Zhao Weidong. The consideration of strengthen the students' humanistic accomplishment in higher vocational education. Education for Chinese After-school(Theory). 2012(09):120-120

[5] Han Wentao. Research on the Humanities training mode of higher vocational education. China staff.2013.3:216-217

[6] Liu Lihong. Integration of humanities curriculum resources, improve students' Humanistic Quality. Vocational education filed.2012(01):194195

[7] Si Juan. The construction of humanistic training system on higher vocational education colleges. Journal of Jilin radio and Television University.2011(08) : 51-52

[8] Liao Junyu. On the construction of three-dimensional cultivation of humanistic quality system at Applied Undergraduate Colleges. Modern Education. 2012.9:37-38

[9] Chen Yuanfu, Han Chun. Study on the engineering of humanistic quality education under the view of Engineering. South Forum. 2009(12) : 4850

[10] Li Heng. Analysis of vocational college humanities education. Journal of Hunan Mass Media Vocational Technical College. 2012.7:90-93 